\title{
SARS-CoV-2 Seroprevalence among health care workers after the first and second pandemic wave
}

\author{
Nathalie de Visscher, MD ${ }^{1^{*}}$; Xavier Holemans, MD ${ }^{1}$; Aline Gillain ${ }^{2}$, Anne \\ Kornreich, MD ${ }^{3}$; Raphael Lagasse, MD, PhD 4, 8, 9 ; Philippe Piette, MD 4; \\ Manfredi Ventura, MD 5; Frédéric Thys, MD, PhD ${ }^{2,6,7^{*}}$
}

\begin{abstract}
${ }^{1}$ Department of Infectiology and Internal Medicine, Grand Hôpital de Charleroi (GHdC), Charleroi, Belgium.
${ }^{2}$ Clinical Research and Translational Unit, Grand Hôpital de Charleroi (GHdC), Charleroi, Belgium.

${ }^{3}$ Department of Laboratory Medicine, Grand Hôpital de Charleroi (GHdC), Charleroi, Belgium.

${ }^{4}$ Department of Medico-Economic Information, Grand Hôpital de Charleroi (GHdC), Charleroi, Belgium.

${ }^{5}$ Department of Medical Management Team, Grand Hôpital de Charleroi (GHdC), Charleroi, Belgium.

${ }^{6}$ Department of Acute and Emergency Medicine, Grand Hôpital de Charleroi (GHdC), Charleroi, Belgium.

${ }^{7}$ Continuing Education Unit UCLouvain Woluwe, Université Catholique de Louvain, Belgium and CEM-ETHICS EA 7446, Université Catholique de Lille, France.

8 Department of Information Technologies, Grand Hôpital de Charleroi (GHdC), Charleroi, Belgium.

${ }^{9}$ School of Public Health, Université Libre de Bruxelles (U.L.B.), Belgium.

* contributed equally to this article."
\end{abstract}

\section{Address correspondence to: Frédéric Thys}

Acute and Emergency Medicine

Grand Hôpital de Charleroi (GHdC)

Grand'Rue, 3

B-6000 Charleroi, Belgium

Phone +32-71-103055

Email: frederic.thys@ghdc.be

\section{Running head: SARS-CoV-2 seroprevalence among health care workers}

Key words: seroprevalence, SARS-CoV-2, health care workers, Belgium, first pandemic wave.

Word Count : 3413 
medRxiv preprint doi: https://doi.org/10.1101/2022.03.03.22271855; this version posted March 6, 2022. The copyright holder for this preprint (which was not certified by peer review) is the author/funder, who has granted medRxiv a license to display the preprint in perpetuity.

\section{Background:}

The Grand Hôpital de Charleroi is a large non-academic Belgian hospital that treated a large number of COVID-19 inpatients. In the context of this pandemic, all professionscombined healthcare workers (HCWs), and not only direct caregivers, are a frontline workforce in contact with suspected and confirmed COVID-19 cases and seem to be a high-risk group for exposure. The aim of our study was to estimate the prevalence of anti-SARS-CoV-2 antibodies in HCWs in our hospital after the first and the second pandemic wave and also to characterize the distribution of this seroprevalence in relation to various criteria.

\section{Methods:}

At the end of the two recruitment periods, a total of 4008 serological tests were performed in this single-center cross-sectional study. After completing a questionnaire including demographic and personal data, possible previous COVID-19 diagnostic test results and/or the presence of symptoms potentially related to COVID-19, the study participants underwent blood sampling and serological testing using DiaSorin's LIAISON $\circledast$ SARS-CoV-2 S1/S2 IgG test for the first phase and LIAISON $\circledast$ SARS-CoV2 TrimericS IgG test for the second phase of this study.

\section{Results:}

302 study participants $(10,72 \%)$ in the first round of the study and $404(33,92 \%)$ in the second round were positive for SARS-CoV-2-lgG antibodies. The prevalence of seropositivity observed after the second wave was 3,16 times higher than after the first wave. We confirmed that direct, prolonged and repeated contact with patients or their environment was a predominant seroconversion factor, but more unexpectedly, that this was the case for all HCWs and not only caregivers. Finally, the notion of high-risk contact seemed more readily identifiable in one's workplace than in one's private life. 
medRxiv preprint doi: https://doi.org/10.1101/2022.03.03.22271855; this version posted March 6, 2022. The copyright holder for this preprint (which was not certified by peer review) is the author/funder, who has granted medRxiv a license to display the preprint in perpetuity. It is made available under a CC-BY 4.0 International license .

\section{Conclusion:}

Our study confirmed that HCWs are at a significantly higher risk of contracting COVID19 than the general population, and suggest that repeated contacts with at-risk patients, regardless of the HCWs' profession, represent the most important risk factor for seroconversion. (Clinicaltrials.gov number, NCT04723290) 
medRxiv preprint doi: https://doi.org/10.1101/2022.03.03.22271855; this version posted March 6, 2022. The copyright holder for this preprint (which was not certified by peer review) is the author/funder, who has granted medRxiv a license to display the preprint in perpetuity.

\section{Introduction}

Coronaviruses have been circulating in the population for a long time and are associated with rather mild respiratory symptoms. The new SARS-CoV-2 belongs to the beta-coronavirus subfamily and is closely genomically-related to SARS-CoV-1 that caused the SARS epidemic in 2002-2003. Severe acute respiratory syndrome coronavirus-2 (SARS-CoV-2) and coronavirus disease 2019 (COVID-19) emerged in December 2019 from Wuhan, Hubei Province, China, and the World Health Organization (WHO) declared it a pandemic situation on March 11, 20201. As of November 19, 2021, WHO reported globally 254847065 confirmed cases and 5120712 total deaths due to COVID-192. On the same date, the Belgian Institute for Public Health (Sciensano) reported 1559998 confirmed cases, 86444 hospital admissions and 26526 deaths in Belgium ${ }^{3}$.

In this unprecedented pandemic context, all professions-combined healthcare workers (HCWs), and not only direct caregivers, are a frontline workforce in contact with suspected and confirmed COVID-19 cases and seem to be a high-risk group for exposure. Several recent meta-analyses have shown that the prevalence of antiSRAS-CoV-2 antibody positive HCWs was high ${ }^{4,5}$. In our setting, though several HCWs showed symptoms suggestive of COVID-19 at the beginning of the epidemic, they were unable to get tested because PCR testing was limited to hospitalized patients in Belgium due to the scarcity of supplies. Furthermore, even when the PCR tests are available, they have a limited sensitivity ${ }^{6}$. Therefore, the detection of antiSARS-CoV-2 antibodies in an individual who previously presented suggestive symptoms related to SARS-CoV-2 infection will confirm the presumptive diagnosis of COVID-19. Anti-SARS-CoV-2 antibody tests are known to be accurate in detecting previous SARS-CoV-2 infection if performed more than 14 days after the onset of 
medRxiv preprint doi: https://doi.org/10.1101/2022.03.03.22271855; this version posted March 6, 2022. The copyright holder for this preprint (which was not certified by peer review) is the author/funder, who has granted medRxiv a license to display the preprint in perpetuity.

It is made available under a CC-BY 4.0 International license .

symptoms, but are much less sensitive if performed earlier ${ }^{7,8}$. Consequently, we assume that studying the evolution of the prevalence of anti-SARS-CoV-2 antibodies among HCWs is important to understand the spread of COVID-19 in hospitals and to evaluate the success of preventive and protective measures implemented in hospitals, which could afterwards be extended to the general population. Furthermore, in terms of crisis management, it is also useful to know the proportion of workers who have already been in contact with the virus in order to optimize the organization of care teams for the benefit of all hospitalized patients, whether or not they are infected with the virus.

This study seeks to evaluate the anti-SARS-CoV-2 seroprevalence of HCWs of the Grand Hôpital de Charleroi (GHdC) at two key moments of the COVID-19 pandemic: after the first wave and after the second wave. The GHdC is a large non-academic institution that was the second hospital in Belgium, and the first in the Walloon Region, to admit the largest number of COVID-19 patients. In addition to studying our HCWs' anti-SARS-CoV-2 seroprevalence, we will also analyze the distribution of this large group of hospital professionals according to age, gender, occupation and geographical location (our care institution being spread over several sites). We will match the HCWs' serological results with their previous COVID-19 history, symptoms and possible known contacts with COVID-19 infected individuals in an effort to contribute to a better description and understanding of the impact of this pandemic within the hospital. We will also analyze the male/female ratio of the participants to address the pending question of possible gender-specific immune responses ${ }^{9}$. 
medRxiv preprint doi: https://doi.org/10.1101/2022.03.03.22271855; this version posted March 6, 2022. The copyright holder for this preprint (which was not certified by peer review) is the author/funder, who has granted medRxiv a license to display the preprint in perpetuity.

\section{Study Design}

Our study was conducted during two distinct inclusion periods: one after the first wave of the pandemic (summer 2020) and the other after the second wave (end of winter 2021). In both recruitment periods, all HCWs at the Grand Hôpital de Charleroi were invited to participate in this monocentric cross-sectional study. None of the HCWs included had received vaccination against COVID-19 prior to their blood being drawn for serological testing. After having given their consent, all participants were asked to fill out a questionnaire which included demographic and personal data, possible prior results of a COVID-19 PCR diagnostic test and/or the presence of symptoms suggestive of a SARS-CoV-2 infection, and knowledge of prior contact with COVID19-infected individuals, whether at work or outside of work. No other questions about prior medical history were asked. Serological sampling and testing were carried out after collecting the completed questionnaires using the DiaSorin LIAISON® SARSCoV-2 S1/S2 IgG test for the first phase and the DiaSorin LIAISON® SARS-CoV-2 TrimericS IgG test for the second phase of this study. Concordance studies between the two kits were done and showed no difference in the interpretation of serological results.

Consent forms, participant's information, questionnaires and test requests were centralized via a highly secure IT platform to ensure data confidentiality throughout the process.

The descriptive statistical evaluation of the questionnaire data, correlated with the laboratory results, used the following methods as appropriate: Chi2- Mann-Whitney Wilcoxon Two-Sample Test and Kruskal-Wallis test. The study protocol was fully approved by the hospital's independent ethics committee and the Clinicaltrials.gov Identifier is NCT04723290. 
medRxiv preprint doi: https://doi.org/10.1101/2022.03.03.22271855; this version posted March 6, 2022. The copyright holder for this preprint (which was not certified by peer review) is the author/funder, who has granted medRxiv a license to display the preprint in perpetuity.

It is made available under a CC-BY 4.0 International license .

\section{Results}

For the first phase of the study, from June 20 to August $112020,3474 \mathrm{HCWs}$ expressed their interest and filled out the informed consent form but finally, only 2817 of them came to be serologically tested. During the second phase of the study, from February 6 to March 31 2021, 1191 HCWs were serologically tested. Thus, over both rounds of this study, we collected 4008 serology results for further analysis. Table 1 presents the distribution of the participants by gender, age and profession category within the hospital for each round. During the first phase of this study, the gender distribution of our sample was 2293 females $(81,4 \%)$ and 524 males $(18,6 \%)$ and perfectly matched that of the general hospital staff i.e. 3,201 females (82\%) and 693 males $(18 \%)$. That same concordance was observed for the age distribution and that was also the trend for the second phase of this study. 
medRxiv preprint doi: https://doi.org/10.1101/2022.03.03.22271855; this version posted March 6, 2022. The copyright holder for this preprint (which was not certified by peer review) is the author/funder, who has granted medRxiv a license to display the preprint in perpetuity.

It is made available under a CC-BY 4.0 International license .

Table 1 : Demographic characteristics, contact with patients and profession among healthcare workers involved in the survey : first and second round

\begin{tabular}{|c|c|c|c|}
\hline & \multicolumn{2}{|c|}{ Summer 2020} & \multirow[b]{2}{*}{$\begin{array}{c}\text { Winter } 2021 \text { (feb-march) } \\
\text { Participants with } \\
\text { serologic test before } \\
\text { immunization } \\
(\mathrm{N}=1191)\end{array}$} \\
\hline & $\begin{array}{c}\text { Participants } \\
\text { to the } \\
\text { survey } \\
(\mathrm{N}=3474)\end{array}$ & \begin{tabular}{|} 
Participants \\
with \\
serologic \\
test \\
$(\mathrm{N}=2817)$ \\
\end{tabular} & \\
\hline & $\%$ & $\%$ & $\%$ \\
\hline \multicolumn{4}{|l|}{ Gender } \\
\hline Females & 81,4 & 81,4 & 82,7 \\
\hline Males & 18,6 & 18,6 & 17,3 \\
\hline \multicolumn{4}{|l|}{ Age Category } \\
\hline$<20$ & 0,1 & 0,1 & 0,1 \\
\hline $20-29$ & 16,4 & 15,5 & 13,1 \\
\hline $30-39$ & 24,2 & 24,8 & 21,8 \\
\hline $40-49$ & 23,7 & 24,1 & 24,9 \\
\hline $50-59$ & 27,7 & 27,9 & 30,1 \\
\hline $60-69$ & 7,8 & 7,6 & 9,7 \\
\hline $70-79$ & 0,2 & 0,1 & 0,3 \\
\hline \multicolumn{4}{|l|}{ Contact with patients } \\
\hline No & 42,9 & 42,6 & 54,2 \\
\hline Yes & 57,1 & 57,4 & 45,9 \\
\hline \multicolumn{4}{|l|}{ Profession } \\
\hline Nurse \& Nurse Aide & 37,3 & 37,5 & 25,7 \\
\hline Physician & 14,8 & 14,8 & 12,3 \\
\hline Other Caregiver & 10,5 & 10,8 & 15,7 \\
\hline Caregivers sub-total & 62,6 & 63,1 & 53,7 \\
\hline Administrative & 15,2 & 16,1 & 25,6 \\
\hline Technical \& Logistics & 5,5 & 5,2 & 4,6 \\
\hline Other & 16,7 & 15,7 & 16,1 \\
\hline
\end{tabular}

Although all professions were represented in the participating HCWs, caregivers, mainly nurses and doctors, were the largest group $(63,1 \%$ after the first pandemic wave versus $53,7 \%$ after the second wave). No significant difference was observed for the caregiving function according to gender. Anti-SARS-CoV-2-IgG antibodies were 
medRxiv preprint doi: https://doi.org/10.1101/2022.03.03.22271855; this version posted March 6, 2022. The copyright holder for this preprint (which was not certified by peer review) is the author/funder, who has granted medRxiv a license to display the preprint in perpetuity.

It is made available under a CC-BY 4.0 International license .

detected in $302(10,72 \%)$ of the 2817 subjects included during the first phase of the study and in $404(33,92 \%)$ of the 1191 subjects included during the second phase, thus showing a 3,16 fold increase in seropositivity of our HCWs (see Table 2). If during the first round of the study, seropositivity was more prevalent in women with a ratio of 1,21 , this trend was reversed in the second round, with a slightly higher, though not significant, seropositivity observed in men with a ratio of 1,13 . In the first round, difference in age-related seropositivity was statistically significant $(p<0.01)$, ranging from $5 \%$ in the $60-69$ age group to $15 \%$ in the younger age group (20-29 years), whereas in the second round, no statistically significant difference $(p=0.06)$ was observed between the lowest seropositivity prevalence observed in the 40-49 age group and the highest one in the younger 20-29 age group. In both rounds, our sample of participants above the age of 69 was too limited to draw any conclusions. The hypothesis that HCWs are a population at high-risk of contracting SARS-CoV-2 infection as a result of patient contact is supported by the following observations from our study: hospital professions who have structurally more numerous, closer and prolonged contacts with patients or their fluid samples, such as caregiver functions, demonstrated a statistically significant difference in terms of seroconversion (RR 2.3 in the first round $(p<0.001)$ and $R R 1.84$ in the second round $(p<0.0001))$. Unexpectedly, after the first wave of the pandemic, we observed that the hospital's technical staff, who had been heavily involved in the many processing jobs in the COVID units, also had a significant seroconversion rate. However, this observation was not reiterated after the second wave. To our current knowledge of the literature, this significant seroconversion rate of ancillary staff of COVID units is original and reported for the first time in this pandemic context. 
medRxiv preprint doi: https://doi.org/10.1101/2022.03.03.22271855; this version posted March 6, 2022. The copyright holder for this preprint (which was not certified by peer review) is the author/funder, who has granted medRxiv a license to display the preprint in perpetuity.

It is made available under a CC-BY 4.0 International license.

Table 2: SARS-CoV-2 seropositivity among participating healthcare workers according to gender, age, contact with patients and profession: situation corresponding to the two rounds of the survey

\begin{tabular}{|c|c|c|c|c|c|c|c|c|c|c|c|c|}
\hline \multicolumn{6}{|c|}{ SUMMER 2020} & \multicolumn{6}{|c|}{ WINTER 2021} & \multirow[t]{2}{*}{ Ratio $2 / 1$} \\
\hline & & \multicolumn{4}{|c|}{$\begin{array}{l}\text { Seropositivity } \\
\text { SARS-CoV-2 }\end{array}$} & & & \multicolumn{4}{|c|}{$\begin{array}{l}\text { Seropositivity } \\
\text { SARS-CoV-2 }\end{array}$} & \\
\hline & $\mathrm{N}$ & $\%$ & $95 \%$ C.I. & Ratio & $P$ & & $\mathrm{~N}$ & $\%$ & $95 \%$ C.I. & Ratio & $\mathrm{P}$ & \\
\hline Total & 2817 & 10,72 & $(9,63-11,92)$ & - & - & Total & 1191 & 33,92 & $(31,29-36,66)$ & - & - & 3,16 \\
\hline Gender & & & & & & $\begin{array}{l}\text { Gender. } \\
\end{array}$ & & & & & & \\
\hline Females & 2293 & 11,08 & $(9,86-12,43)$ & 1,21 & \multirow{2}{*}{ NS } & Females & 985 & 33,20 & $(30,33-36,20)$ & 1,00 & \multirow{2}{*}{ NS } & 3,00 \\
\hline Males & 524 & 9,16 & $(6,98-11,94)$ & 1,00 & & Males & 206 & 37,38 & $(30,75-44,37)$ & 1.13 & & 4,08 \\
\hline & & & & & & & & & & & & \\
\hline Age Category & & & & & & Age Category & & & & & & \\
\hline$<20$ & 2 & 0 & - & - & \multirow{7}{*}{0,005} & $<20$ & 1 & 0 & - & - & \multirow{7}{*}{ NS } & \\
\hline $20-29$ & 436 & 14,91 & $(11,87-18,56)$ & 1,58 & & $20-29$ & 156 & 44.23 & $(36,29-52,39)$ & 1,46 & & 2,97 \\
\hline $30-39$ & 698 & 9,89 & $(7,89-12,32)$ & 1,05 & & $30-39$ & 260 & 33,08 & $(27,39-39,16)$ & 1,09 & & 3,34 \\
\hline $40-49$ & 678 & 9,44 & $(7,46-11,87)$ & 1,00 & & $40-49$ & 297 & 30,30 & $(25,13-35,88)$ & 1,00 & & 3,21 \\
\hline $50-59$ & 786 & 11,7 & $(9,64-14,14)$ & 1,24 & & $50-59$ & 358 & 35,20 & $(30,43-40,28)$ & 1,16 & & 3,01 \\
\hline $60-69$ & 213 & 5,16 & $(2,61-9,05)$ & 0,55 & & $60-69$ & 116 & 27.59 & $(19,70-36,66)$ & 0,91 & & 5,35 \\
\hline $70-79$ & 4 & 25 & $(0,63-80,59)$ & - & & $70-79$ & 3 & 33,33 & $(0,84-90,57)$ & - & & \\
\hline & & & & & & & & & & & & \\
\hline Contact with patients & & & & & & Contact with patients & & & & & & \\
\hline No & 1183 & 6,17 & $(4,94-7,69)$ & 1,00 & \multirow{2}{*}{$P<0,0001$} & No & 561 & 24,42 & $(21,05-28,14)$ & 1,00 & \multirow{2}{*}{$P<0,0001$} & 3,96 \\
\hline Yed & 1594 & 14,3 & $(12,67-16,11)$ & 2,32 & & Yes & 475 & 45,05 & $(40,64-49,55)$ & 1,84 & & 3,15 \\
\hline Trade & & & & & & Trade & & & & & & \\
\hline Nurse \& Nurse Aide & 1057 & 16,08 & $(13,99-18,42)$ & 4,05 & \multirow{6}{*}{$P<0,0001$} & Nurse \& Nurse Aide & 306 & 48,04 & $(42,50-53,63)$ & 2,19 & \multirow{6}{*}{$P<0,0001$} & 2,99 \\
\hline Physician & 418 & 9,81 & $(7,31-13,04)$ & 2,47 & & \begin{tabular}{|l|} 
Physician \\
\end{tabular} & 146 & 43,15 & $(34,99-51,60)$ & 1,96 & & 4,40 \\
\hline Other Caregiver & 303 & 9,24 & $(6,47-13,03)$ & 2,33 & & Other Caregiver & 187 & 24,60 & $(18,61-31,41)$ & 1,12 & & 2,66 \\
\hline Administrative & 453 & 3,97 & $(2,53-6,19)$ & 1,00 & & \begin{tabular}{|l} 
Administrative \\
\end{tabular} & 305 & 21,97 & $(17,69-26,95)$ & 1,00 & & 5,53 \\
\hline Technical \& Logistics & 145 & 13,1 & $(8,08-19,7)$ & 3,30 & & Technical \& Logistics & 55 & 34,55 & $(22,24-48,58)$ & 1,57 & & 2,64 \\
\hline Other & 441 & 5,9 & $(4,05-8,5)$ & 1,49 & & \begin{tabular}{|l|} 
Other \\
\end{tabular} & 192 & 32,29 & $(25,74-39,40)$ & 1,47 & & 5,47 \\
\hline Caregivers sub-total & 1778 & 13,44 & $(11,94-15,11)$ & 3,39 & $P<0,0001$ & Caregivers sub-total & 639 & 40,06 & $(36,33-43,91)$ & & $P<0,0001$ & 2,98 \\
\hline
\end{tabular}

In both rounds of our study, participants were asked if they had had close contact with COVID-19-positive people at work or in their private lives, with no time limit for the first phase and going back three months for the second phase (Table 3). In the first phase of our study, most participants could not easily provide this information, probably due to the scarcity of PCR tests at that time, whereas in the second phase of the study, more participants could identify this type of contact. In the first round, only 188 study participants $(6.7 \%)$ reported close contact with a case of COVID-19 outside of work, and among these, $17 \%$ tested positive for anti-SARS-CoV-2 antibodies, whereas the rest of the study population, who answered "no" or "unknown" to this question, showed a $10.3 \%$ seropositivity rate $(p=0.004)$. In the second round, these reports increased to 270 study participants (22.67\%) among whom 45\% were seropositive. More 
medRxiv preprint doi: https://doi.org/10.1101/2022.03.03.22271855; this version posted March 6, 2022. The copyright holder for this preprint (which was not certified by peer review) is the author/funder, who has granted medRxiv a license to display the preprint in perpetuity.

It is made available under a CC-BY 4.0 International license.

surprisingly, even though close contacts with COVID-19 patients in the professional setting were more readily identifiable during the first round, with 1054 respondents $(37.4 \%)$ reporting them, the seropositivity rate $(17.6 \%)$ was similar in this group to the one in the private setting. The findings were similar in the second round where a highrisk contact was reported by 270 respondents $(22.7 \%)$ outside of work and by 288 respondents $(24.2 \%)$ at work, and both groups had a similar seroconversion rate of $45.2 \%$ and $47.2 \%$ respectively.

Table 3: SARS-CoV-2 seropositivity among participating healthcare workers according to close contact in the surrounding or at work: situation corresponding to the two rounds of the survey

\begin{tabular}{|c|c|c|c|c|c|}
\hline \multicolumn{6}{|c|}{ SUMMER 2020} \\
\hline & & \multicolumn{4}{|c|}{$\begin{array}{l}\text { Seropositivity } \\
\text { SARS-CoV-2 }\end{array}$} \\
\hline & $\mathrm{N}$ & $\%$ & $95 \%$ C.I. & Ratio & $\mathrm{P}$ \\
\hline \multicolumn{6}{|c|}{$\begin{array}{l}\text { Close contact in the } \\
\text { surrounding }\end{array}$} \\
\hline Yes & 188 & 17,02 & $(11,94-23,17)$ & 1,66 & \multirow{2}{*}{0,004} \\
\hline Unknown & 2629 & 10,27 & $(9,17-11,49)$ & 1,00 & \\
\hline \multicolumn{6}{|c|}{ Close contact at work } \\
\hline Yes & 1054 & 17,55 & $(15,37-19,97)$ & 2,64 & \multirow{2}{*}{$P<0,0001$} \\
\hline Unknown & $\mid 1763$ & 6,64 & $(5,57-7,9)$ & 1,00 & \\
\hline & & & & & \\
\hline
\end{tabular}

\begin{tabular}{|c|c|c|c|c|c|}
\hline \multicolumn{6}{|c|}{ WINTER 2021} \\
\hline & & \multicolumn{4}{|c|}{$\begin{array}{l}\text { Seropositivity } \\
\text { SARS-CoV-2 }\end{array}$} \\
\hline & $\mathrm{N}$ & $\%$ & 95 \% C.I. & Ratio & $P$ \\
\hline & & & & & \\
\hline \multicolumn{6}{|c|}{$\begin{array}{l}\text { Close contact in the } \\
\text { surrounding }\end{array}$} \\
\hline Yes & 270 & 45,19 & $(48,67-60,85)$ & 1,48 & \multirow{2}{*}{$P<0,0001$} \\
\hline Unknown & 921 & 30,62 & $(27,73-33,67)$ & 1,00 & \\
\hline \multicolumn{6}{|c|}{ Close contact at work } \\
\hline Yes & 288 & 47,22 & $(41,34-53,16)$ & 1,59 & \multirow{2}{*}{$P<0,0001$} \\
\hline Unknown & 903 & 29,68 & $(26,79-32,74)$ & 1,00 & \\
\hline & & & & & \\
\hline
\end{tabular}

Finally, in both rounds of the study, participants were asked if they had previously presented symptoms suggestive of COVID-19 (Table 4). In the first round, 161 participants (5.7\%) answered "yes", though only 133 of them were confirmed with a PCR test. Those HCWs showed $79.5 \%$ seropositivity, whereas the 1264 who declared not having had symptoms of COVID-19 had a seropositivity rate of $4 \%$, which may correspond to asymptomatic forms of the disease. In the second round, it was interesting to observe that the $290(24,4 \%) \mathrm{HCW}$ who reported having had prior symptoms suggestive of COVID-19 had a significantly higher seropositivity rate than those who had had no symptoms $(87.6 \% ; p<0.0001)$. 
medRxiv preprint doi: https://doi.org/10.1101/2022.03.03.22271855; this version posted March 6, 2022. The copyright holder for this preprint (which was not certified by peer review) is the author/funder, who has granted medRxiv a license to display the preprint in perpetuity.

It is made available under a CC-BY 4.0 International license .

Table 4: Seropositivity according to the "symptoms suggestive of Covid-19" response

\begin{tabular}{|c|c|c|c|c|c|}
\hline \multicolumn{6}{|c|}{ SUMMER 2020} \\
\hline & & \multicolumn{4}{|c|}{$\begin{array}{l}\text { Seropositivity } \\
\text { SARS-CoV-2 }\end{array}$} \\
\hline & $\mathrm{N}$ & $\%$ & 95 \% C.I. & Ratio & $P$ \\
\hline \multicolumn{6}{|c|}{$\begin{array}{l}\text { Symptoms } \\
\text { suggestive } \\
\text { of Covd-19 }\end{array}$} \\
\hline Yes & 161 & 79,5 & $(72,44-85,45)$ & 20,08 & \multirow{3}{*}{$P<0,0001$} \\
\hline No & 1264 & 3,96 & $(3,01-5,18)$ & 1 & \\
\hline Unknown & 1392 & 8,91 & $(7,52-10,52)$ & 2,25 & \\
\hline
\end{tabular}

\begin{tabular}{|c|c|c|c|c|c|}
\hline \multicolumn{6}{|c|}{ WINTER 2021} \\
\hline & & \multicolumn{4}{|c|}{ Seropositivity } \\
\hline & & \multicolumn{4}{|c|}{ SARS-CoV-2 } \\
\hline & $\mathrm{N}$ & $\%$ & 95 \% C.I. & Ratio & $\mathrm{P}$ \\
\hline \multicolumn{6}{|c|}{$\begin{array}{l}\text { Symptoms } \\
\text { suggestive } \\
\text { of Covd-19 }\end{array}$} \\
\hline Yes & 290 & 87,59 & $(83,23-91,15)$ & 6,77 & \multirow{3}{*}{$P<0,0001$} \\
\hline No & 657 & 12,94 & $(10,59-15,72)$ & 1 & \\
\hline Unknown & 244 & 26,64 & $(21,20-32,65)$ & 2,06 & \\
\hline
\end{tabular}

\section{Discussion}

The main aim of this study was to determine the anti-SARS-CoV-2 seroprevalence in health care workers at the Grand Hôpital de Charleroi, Belgium, at two key moments in time, i.e. after the first and the second pandemic waves. Its secondary objective was to examine the distribution of this anti-SARS-CoV-2 prevalence by gender, age and type of profession, but also in relation to possible previous symptoms suggestive of COVID-19 and the notion of high-risk contact with an infected person in a large group of health care workers. Our study is one of the few published studies on the seroprevalence of SARS-CoV-2 in all professions employed by a hospital and shows a relatively high proportion of HCWs who are IgG positive for SARS-CoV-2 compared to other centers in Europe. Overall participation was high (75\% of all hospital staff) and fully representative of our staff in terms of gender and age distribution in both rounds of the study. All hospital professions were represented in our overall study sample, although the proportion of direct caregivers (mainly doctors and nurses) was higher than the rest. Seropositivity rate for SARS-CoV-2-IgG antibodies was $10,72 \%$ (302 among 2817 study participants) after the first pandemic wave, and 33,92\% (404 among 1191 study participants) after the second pandemic wave. The seroprevalence in our 
medRxiv preprint doi: https://doi.org/10.1101/2022.03.03.22271855; this version posted March 6, 2022. The copyright holder for this preprint (which was not certified by peer review) is the author/funder, who has granted medRxiv a license to display the preprint in perpetuity.

cohort thus showed a 3,16 fold increase in the second round of our study. We confirmed that repeated, direct and prolonged contact with patients or their environment was a significant seroconversion factor. Finally, the notion of high-risk contact seemed easier to identify in the professional setting than in the private setting and the identification of high-risk contact were easier during the second wave in both settings.

The COVID-19 pandemic is arguably the most important and rapidly evolving infectious public health issue in the world since the AIDS pandemic, and worldwide efforts are made to suppress or eliminate its spread by all means including hand hygiene, social distancing, early screening, diagnosis and quarantine ${ }^{10,11}$. In this context, knowledge of the SARS-CoV-2 seroprevalence of the population, combined with data from COVID-19 diagnostic tests, are useful tools to assess the proportion of the population infected with SARS-CoV-2 in a recent or somewhat delayed manner. These results should make it possible to calibrate responses to the waves of this pandemic and guide policy makers in the fight against it. A recent meta-analysis of SARS-CoV-2 seroprevalence in the world population has shown that although it is geographically heterogeneous, ranging from $0,37 \%$ to $22,1 \%$, the absence of active immunization is estimated around $3,38 \%$ overall ${ }^{12}$. Another recent study in Croatia analyzed the seroprevalence and the neutralizing antibody response in the general Croatian population after the first and second pandemic waves. This study showed a significant difference in the overall seroprevalence rate after the first wave (ELISA 2,2\%, Virus Neutralization Test (VNT) 0,2\%) and second wave (ELISA 25,1\%, VNT 18,7\%) ${ }^{13}$. The knowledge of the seroprevalence in health care workers is also important, both for the organization of care within the hospital and for the implementation of global public health policies. The prevalence of SARS-CoV-2 antibodies among HCWs is shown to 
medRxiv preprint doi: https://doi.org/10.1101/2022.03.03.22271855; this version posted March 6, 2022. The copyright holder for this preprint (which was not certified by peer review) is the author/funder, who has granted medRxiv a license to display the preprint in perpetuity.

It is made available under a CC-BY 4.0 International license .

be high. After the first wave, a large systematic review and meta-analysis of 127480 healthcare workers estimated an overall seroprevalence of $8,7 \%^{5}$. This figure was slightly lower than previous meta-analyses, which estimated it at $10,1 \% 4,14$. Seroprevalence varied by region, with $12,7 \%$ in North America, $8,5 \%$ in Europe, $8,2 \%$ in Africa and 4\% in Asia $^{5}$. After the second wave, several authors reported higher overall prevalence rates among HCWs in different parts of the world: $20,8 \%$ in Kenya ${ }^{15}$, $23,65 \%$ in Ahmedabad (India) ${ }^{16}$ and even $31,6 \%$ in Spain ${ }^{17}$. In our study, the measured seroprevalence was $10,72 \%$ after the first wave, which was higher than the values reported in the various studies previously carried out after the first wave in Belgium (that ranged between $6,4 \%$ and $7,7 \%^{18,19}$ ), and $33,92 \%$ after the second wave. This difference could be due to the fact that the province of Hainaut, where our hospital is located, is one of the Belgian provinces that bore the heaviest burden of COVID-19 infections in Belgium. This explanation is supported by the findings that seroprevalence rates in HCWs reported in the literature are proportional to levels of exposure to SARSCoV-2 20,21 . On this matter, Prakash O et al. demonstrated that the seropositivity among healthcare workers by area in India was closely correlated with the number of cases reported in the respective area. Surprisingly, they also found that the rate of seropositivity among healthcare workers in the oldest and most severely affected areas was lower than in more recently affected areas. The authors speculated that IgG antibodies may not be lasting ${ }^{16}$. Another significant factor to consider is the timing of the test in relation to the course of the epidemic wave. It is noteworthy that some recent publications observed variations in the seroprevalence of anti-SARS-CoV-2 antibodies among different groups of healthcare workers. The highest seroprevalence was observed among those working in acute or emergency medicine or in general internal medicine, while the lowest seroprevalence was observed among those working in 
medRxiv preprint doi: https://doi.org/10.1101/2022.03.03.22271855; this version posted March 6, 2022. The copyright holder for this preprint (which was not certified by peer review) is the author/funder, who has granted medRxiv a license to display the preprint in perpetuity.

It is made available under a CC-BY 4.0 International license .

intensive care medicine ${ }^{22}$. These findings support the hypothesis that the different risks of exposure to SARS-CoV-2 exist in the hospital environment. Intensive care units have often been pointed as high-risk environments and have therefore benefited from the use of optimized personal protective equipment (PPE). Furthermore, in a COVID unit, the caregivers wears the same PPE as they go from one patient to the next. That is not the case in an emergency department, where the caregivers constantly change their PPE between patients so as to limit the risk of spreading the disease. In our institution, we have observed the same phenomenon with the dedicated COVID-19 intensive care or hospitalization units. Surprisingly, a subgroup from the first round, the technical staff of the hospital, showed a higher proportion of seroconversion than that of certain subgroups of caregivers (see Table 2). This group was heavily involved in the transformation work needed to setup the COVID units. We assumed that they were subjected to an environment with high exposure to the virus and that the specificity of their work required them to frequently change their PPE when they had to take over new tools or materials for their technical work. These observations tend to show that frequently changing PPE in a potentially contaminated environment is in itself a contamination risk, and even more so if professional training for this is insufficient or non-existent. The fact that we did not observe this increased seroconversion rate in this subgroup in the second round of our study reinforces our hypothesis, since most of the transformation work took place during the first wave and that, by the second wave, staff training for changing PPE was improved. This combination of factors could explain this original observation.

It has been reported that gender may impact immune responses to COVID-1923. Gender-related differences at several levels (infection and severity) are reported in the literature ${ }^{24,25}$. We therefore also wanted to address this gender issue in our study (see 
medRxiv preprint doi: https://doi.org/10.1101/2022.03.03.22271855; this version posted March 6, 2022. The copyright holder for this preprint (which was not certified by peer review) is the author/funder, who has granted medRxiv a license to display the preprint in perpetuity.

It is made available under a CC-BY 4.0 International license.

Table 2). Although we found a higher seroprevalence among women in the first round of our study, we were not able to demonstrate a significant difference for this parameter, but we must keep in mind that our univariate approach did not consider other exposure factors. The reversal of this finding in the second round of our study, though still not statistically significant, with a higher seroprevalence among men, led us to reject the impact of gender on seroprevalence for our cohort ${ }^{26}$.

And lastly, we showed that, in the first round of our study, a high-risk contact was easier to confirm in the workplace than in the private setting, though this was still difficult for healthcare workers due to the scarcity of PCR tests, especially for outpatients. The increasing availability over time of PCR tests and the implementation of the contacttracing scheme allowed a better assessment of risk-related contacts thereafter ${ }^{27}$. Despite those difficulties, it is noteworthy that among HCWs who declared having had a high-risk contact, the seroconversion rate was similar in both non-work and work settings $(17,02 \%$ vs $17,55 \%$ in the first round and $45,19 \%$ vs $47,22 \%$ in the second round). This leads us to believe that high-risk contacts were underestimated and/or the transmission rate was low during the first wave, compared with the second wave, where high-risk contacts were better identified and the transmission rate was increased with the emergence of the alpha-variant of the virus. Interestingly, HCWs who declared not having had a high-risk contact or not knowing, also had a similar seroconversion rate in both non-work and work settings, especially in the second round of this study $(30,62 \%$ vs $29,68 \%)$, thus indicating that asymptomatic transmission was substantial in both settings and underlining the importance of applying barrier measures at all times. It should be noted that a meta-analysis estimated that nosocomial transmission was the source of SARS-CoV-2 infection in approximately $44 \%$ of $\operatorname{cases}^{28}$. For this reason, some authors suggested regular anti-SARS-CoV-2 IgG screening of 
medRxiv preprint doi: https://doi.org/10.1101/2022.03.03.22271855; this version posted March 6, 2022. The copyright holder for this preprint (which was not certified by peer review) is the author/funder, who has granted medRxiv a license to display the preprint in perpetuity.

It is made available under a CC-BY 4.0 International license .

healthcare workers to better identify risk factors and adapt the organization of care. It was demonstrated that healthcare workers who care for COVID-19 patients and identify a high-risk contact have a higher seroprevalence ${ }^{20}$. The identification of such a contact should lead to the systematic use of adequate PPE in order to limit the risk of contamination.

In conclusion, though this study has the limitation of being monocentric, it has the advantage of pinpointing the time between possible exposure to SARS-CoV-2 and seroconversion across a wide variety of professions within our hospital, giving a more accurate estimation of seroprevalence among our HCWs, which is indeed slightly higher than what has been reported in previous studies conducted in our country and in Europe during both pandemic waves. It confirmed that healthcare workers represent a population that is at significantly higher risk of contracting COVID-19 than the general population. We suggest that the notion of repeated contact with high-risk patients and the regular change PPE represent the most important risk factors for seroconversion. In this context, absolute adherence to infection prevention and barrier measures, sufficient and adequate personal protective equipment, as well as early recognition, identification and isolation of healthcare workers infected with SARS-CoV-2 remain mandatory to reduce the risk of COVID-19 infection and transmission, especially since the notion of high-risk contact, although more readily accessible in the professional than in the private setting, continues to be elusive.

\section{Acknowledgements}

The authors would like to thank the management of the hospital who made it possible for this study to be carried out under excellent conditions, as well as all the departments and people who worked on 
medRxiv preprint doi: https://doi.org/10.1101/2022.03.03.22271855; this version posted March 6, 2022. The copyright holder for this preprint (which was not certified by peer review) is the author/funder, who has granted medRxiv a license to display the preprint in perpetuity.

It is made available under a CC-BY 4.0 International license .

this project. The authors warmly thank all the staff members in each profession of the hospital who agreed to be included in this study and for their devotion at the bedside of patients with COVID-19. 


\section{Bibliography}

${ }^{1}$ Li Q, Guan X, Wu Pet al. Early transmission dynamics in Wuhan, China, of novel coronavirus-infected pneumonia. N Engl J Med 2020 ; $382: 1199 \mathrm{e} 207$.

2 World Health Organization ; WHO Health Emergency Dashboard. https://covid19.who.int/ (last accessed March 2021).

${ }^{3} \mathrm{https} / / /$ covid-19.sciensano.be/sites/default/files/Covid19/COVID-19_Daily\%20report_20210303\%20-\%20FR.pdf

${ }^{4}$ Sahu AK, Amrithanand VT, Mathew R, Aggarwal P, Nayer J, Bhoi S. COVID-19 in health care workers - a systematic review and meta-analysis.

Am J Emerg Med. $2020 ; 38: 1727-1731$.

${ }^{5}$ Galanis P, Vraka I, Fragkou D, Bilali A, Kaitelidou D. Seroprevalence of SARS-CoV-2 antibodies and associated factors in health care workers: a systematic review and meta-analysis. J Hosp Infect. 2020 Nov 16;108:120-134.

${ }^{6}$ Miller TE, Garcia-Beltran WF, Bard AZ et al. Clinical sensitivity and interpretation of PCR and serological COVID-19 diagnostics for patients presenting to the hospital. FASEB J. $2020 ; 34(10): 13877-13884$.

${ }^{7}$ Deeks JJ, Dinnes J, Takwoingi Y, Davenport C, Spijker R, Taylor-Phillips S. Cochrane COVID-19 Diagnostic Test Accuracy Group. Antibody tests for identification of current and past infection with SARS-CoV-2. Cochrane Database Syst Rev. $2020 ; 6$ : CD013652.

${ }^{8}$ Sethuraman N, Jeremiah SS, Ryo A. Interpreting Diagnostic Tests for SARS-CoV-2. JAMA 2020 Jun $9 ; 323(22): 2249-2251$.

${ }^{9}$ Jin JM, Bai P, He W et al. Gender Differences in Patients With COVID-19: Focus on Severity and Mortality.

Front Public Health $2020 ; 29 ; 8: 152$

${ }^{10}$ Nussbaumer-Streit B, Mayr V, Dobrescu AI et al. Quarantine alone or in combination with other public health measures to control COVID-19: a rapid review. Cochrane Database Systematic Review 2020 April 08. doi: 10.1002/14651858.CD013574

${ }^{11}$ Sjödin H, Wilder-Smith A, Osman S, Farooq Z, Rocklöv J. Only strict quarantine measures can curb the coronavirus disease (COVID-19) outbreak in Italy, 2020. Eurosurveillance $2020 ; 25$ (13)

${ }^{12}$ Rostami A, Sepidarkish M, Leeflang M et al. SARS-CoV-2 seroprevalence worldwide: a systematic review and meta-analysis. Clin Microbiol Infect. 2020 Oct 24; S1198743X (20) 30651-0.

${ }^{13}$ Vilibic-Cavlek T, Stevanovic V, Ilic M et al. SARS-CoV-2 Seroprevalence and Neutralizing Antibody Response after the First and Second COVID-19 Pandemic Wave in Croatia. Pathogens. 2021 Jun 20;10(6):774.

${ }^{14}$ Meylan S, Dafni U, Lamoth F et al. SARS- CoV-2 seroprevalence in healthcare workers of a Swiss tertiary care centre at the end of the first wave: a cross- sectional study. BMJ Open 2021;11:e049232.

15 O Etyang A, Lucinde R, Karanja H et al. Seroprevalence of Antibodies to Severe Acute Respiratory Syndrome Coronavirus 2 Among Healthcare Workers in Kenya. Clinical Infectious Diseases, 2021; ciab346, https://doi.org/10.1093/cid/ciab346.

${ }^{16}$ Prakash O, Solanki B, Sheth J et al. SARS-CoV2 IgG antibody: Seroprevalence among health care workers. Clin Epidemiol Glob Health. $2021 ; 11: 100766$.

${ }^{17}$ GalanMI, Velasco M, Casas L et al. Hospital-Wide SARS-CoV-2 seroprevalence in health care workers in a Spanish teaching hospital.

Enferm Infecc Microbiol Clin (Engl Ed) 2020 18;S0213-005X(20)30418-3.

${ }^{18}$ Steensels D , Oris E , Coninx L et al. Hospital-Wide SARS-CoV-2 Antibody Screening in 3056 Staff in a Tertiary Center in Belgium. JAMA. 2020 Jul 14; $324(2)$ : $195-$ 197.

${ }^{19}$ Mortgat L, Barbezange C, Fischer N et al. SARS-CoV-2 Prevalence and Seroprevalence among Healthcare Workers in Belgian Hospitals: Baseline Results of a Prospective Cohort Study.

${ }^{20}$ Venugopal U, Jilani N, Rabah S et al. SARS-CoV-2 seroprevalence among health care workers in a New York City hospital: A cross-sectional analysis during the COVID19 pandemic. Int J Infect Dis. 2021 Jan;102:63-69.

${ }^{21}$ Psichogiou M, Karabinis A, Pavlopoulou ID et al. Antibodies against SARS-CoV-2 among health care workers in a country with low burden of COVID-19. PLoS One. 2020 Dec 3;15(12): e0243025. 
${ }^{22}$ Shields A , Faustini SE , Perez- Toledo M et al. SARS-CoV-2 seroprevalence and asymptomatic viral carriage in healthcare workers: a cross-sectional study. Thorax. 2020 Dec;75(12):1089-1094

${ }^{23}$ Chen N, Zhou M,Dong X et al. Epidemiological and clinical characteristics of 99 cases of 2019 novel coronavirus pneumonia in Wuhan, China : a descriptive study. Lancet $2020 ; 395: 507-513$.

${ }^{24} \mathrm{Wu} Z$, McGoogan JM. Characteristics of and important lessons from the coronavirus disease 2019 (COVID-19) outbreak in China: summary of a report of 72314 cases from the Chinese center for disease control and prevention. JAMA $2020 ; 323(13)$ : 1239-1242.

${ }^{25}$ Dudley JP, Lee NT. Disparities in age- specific morbidity and mortality from SARS- CoV-2 in China and the Republic of Korea. Clin. Infect. 2020 Dis. https://

doi.org/10.1093/cid/ciaa354.

${ }^{26}$ Scully E, Haverfield J, Ursin R, Tannenbaum C, Klein S. Considering how biological sex impacts immune responses and COVID-19 outcomes. Nature Reviews Immunology $2020 ; 20: 442-447$.

${ }^{27}$ Behrens G, Cossmann A, Stankov M et al. Perceived versus proven SARS-CoV-2-specific immune responses in health-care professionals. Infection. 2020 Aug;48(4):631634.

${ }^{28}$ Zhou Q, Gao Y, Wang X et al. Nosocomial infections among patients with COVID-19, SARS and MERS : a rapid review and meta-analysis. medRxiv. 2020 2020;2020.04.14.20065730. 